\title{
Clinical validation of genetic tests
}

There has been exponential growth of information regarding genetic susceptibilities to common, chronic conditions that are important public health concerns for our society, and a substantial amount of new information is anticipated as the completion of the Human Genome Project draws near.' Understanding how to apply this information in the practice of medicine and how to integrate genetic information into public health efforts are new challenges resulting from these discoveries.

Numerous loci have been identified that are associated with the most prevalent of diseases including coronary heart disease, stroke, diabetes, and many common cancers. ${ }^{2-5}$ Knowledge of the genetic factors that contribute to the susceptibility and natural history of these diseases can allow for improved disease management and prevention through the development of diagnostic and presymptomatic tests and therapies that target specific genetic risks. ${ }^{6}$ In the public health arena, presymptomatic tests may identify high-risk individuals who may benefit from early detection and prevention strategies that are different from those recommended for the average risk population. However, many gene discoveries have been made in high-risk families or select groups ${ }^{7}$ thereby limiting the generalizability regarding genotype prevalence and penetrance values derived from these studies.

In this issue of Genetics in Medicine, Yang and colleagues ${ }^{8}$ describe a model for determining the clinical validity of genetic tests used to determine susceptibility to complex diseases, as well as the attributable risk of genotypes associated with a disease susceptibility. They illustrate their simple yet useful techniques with two examples, the risk for neural tube defects associated with the MTHFR C677T mutation and the risk for breast cancer associated with BRCAl gene mutations. In the case of the MTHFR mutation, they found that the sensitivity and positive predictive values are low, $19.2 \%$ and $0.14 \%$, respectively. The negative predictive value of the MTHFR mutation was high at $99.9 \%$, and the population attributable fraction of neural tube defects due to homozygosity was $7.9 \%$. In the case of BRCAl mutations, using absolute breast cancer risks from registry data and relative risks from case-control studies the authors estimated age-specific penetrance values for breast cancer, which were similar to published penetrance estimates ${ }^{9,10}$ illustrating the validity of their methods.

The authors' approach using data derived from populationbased case-control studies provides a framework to understand the basic relationship between a genotype and disease status. In this broad context, this method can provide the basis for determining when a genetic test should be offered to the population as a screening test to identify individuals at increased risk who may be deserving of enhanced preventive strategies and for whom management would otherwise be dif- ferent. In addition, scarce public health resources can be appropriately allocated with knowledge of clinical validity and attributable risk associated with a particular genotype within the population.

However, as the authors suggest, their method has some limitations including the limited amount of information available from population-based registries regarding risk factors that would permit stratum-genotype-specific risk estimates, as well as the fact that a genotype may predict risk for more than one condition. These limitations may be particularly important in the clinical setting where individualization of risk is the goal. Unlike breast cancer risk associated with BRCAl gene mutations, the genetic susceptibilities to most complex diseases are probably due to the interaction of multiple genetic factors of moderate risk with high frequency that interact with the environment." The penetrance of any single allele may have a limited impact on disease status. Thus, translating the penetrance estimates derived from the study methods of Yang et al. ${ }^{8}$ may underestimate an individual's risk for disease if other risk factors are also present. For example, if the analysis of the MTHFR C677T mutation associated with neural tube defects were stratified on the presence of folate status or family history of neural tube defects, the positive predictive value and attributable risk of the MTHFR mutation might have been more favorable.

An approach that considers the interaction of multiple genetic and environmental susceptibility factors would be preferable for identifying susceptibility to complex diseases within the population and when trying to individualize genetic risk in the clinical setting. However, developing mathematical models capable of quantifying these relationships might be too complex and impractical for estimating risks in the population.

Familial aggregation of complex diseases represents shared genetic and environmental risk factors. Thus, as an alternative strategy the family history may be an excellent marker of genetic susceptibility to common, complex diseases and it can serve as a marker for multiple conditions for which familial aggregation has been described.'2 Even with the example of highly penetrant BRCA1 mutations, in families with multiple cases of breast cancer that lack ovarian cancer, a recent heterogeneity analysis showed that a significant proportion of susceptibility in such families is due to genes other than BRCA1 and BRCA2. ${ }^{13}$ This suggests that until most of the susceptibility alleles for breast cancer are identified, family history may be a better initial determinant of genetic risk than a genetic test. In support of this, a recent study has shown that the family history of breast cancer may be the most important predictor of the presence of a BRCA gene mutation. ${ }^{14}$ Thus, the collection and interpretation of the family history may allow for the determination of genetic susceptibility for several common, complex 
conditions and should be considered as an alternative initial approach for identifying individuals with a genetic susceptibility to common diseases.

Perhaps an ideal approach for the identification and quantification of genetic susceptibility to common, complex diseases would include the combination of determining the clinical validity of genetic tests from population-based casecontrol designs stratified by family history data that would include the number of relatives affected with the disease of interest and related conditions and ages of onset. Thus, in addition to allocation of resources for DNA banking of registry participants, this would require a commitment from the registries to collect family history information in a comprehensive and systematic fashion.

In recognition of the value of population-based data in answering fundamental questions related to the genetic aspects of disease, the National Institute of General Medical Sciences (NIGMS) has recently held a workshop to consider the scientific benefits and the potential risks of maintaining genetic data from defined populations. ${ }^{14}$ The NIGMS supports the Human Genetic Cell Repository, which supplies cell lines and DNA samples to investigators worldwide. This workshop focused on developing recommendations that would protect populations participating in human genetics research. The guidelines proposed by the NIGMS workshop might provide the framework for the human subjects protections needed for the implementation of a population-based model for clinical validation of genetic tests.
Maren T. Scheuner, MD, MPH

Cedars-Sinai Medical Center Los Angeles, California

\section{References}

1. Collins FS, Jegalian KG. Deciphering the code of life. Scientific Am 1999;281:86-91.

2. Cheng S, Grow MA, Pallaud C, Klitz W, Erlich HA, Visvikis S, Chen IJ, Pullinger CR, Malloy MI, Siest G, Kane JP. A multilocus genotyping assay for candidate markers of cardiovascular disease risk. Genome Res 1999;9:936-949.

3. Alberts MJ, ed. Genetics of cerebrovascular disease. Armonk, New York: Futura Publishing Company, Inc., 1999.

4. Scheuner MT, Raffel LJ, Rotter JI. Genetics of diabetes. In: Alberti KGMM, Zimmet P, Defronzo RA, eds. New York: John Wiley \& Sons, 1997:37- 88.

5. Vogelstein B, Kinzler KW, eds. The genetic basis of human cancer. New York: McGraw-Hill, 1998.

6. van Ommen GJB, Bakker E, den Dunnen JT. The human genome project and the future of diagnostics, treatment, and prevention. Lancet 1999;354:SI5-S10.

7. Khoury MJ. Human genome epidemiology: Translating advances in human genetics into population-based data for medicine and public health. Genetics in Medicine 1999;1:71-73.

8. Yang Q, Khoury MJ, Coughlin SS, Sun F, Flanders WD. On the use of populationbased registries in the clinical validation of genetic tests for disease susceptibility. Genetics in Medicine 2000;2:xxx-xxx.

9. Claus EB, Risch N, Thompson WD. Genetic analysis of breast cancer in the Cancer and Steroid Hormone Study. Am J Hum Genet 1991;48:232-242.

10. Ford D, Easton DF, Peto J. Estimates of the gene frequency of BRCA1/BRCA2 and its contribution to breast and ovarian cancer incidence. Am J Hum Genet 1995;57: 1457-1462.

11. Risch N, Merikangas K. The future of genetic studies of complex human diseases. Science 1996;273:1516-1517.

12. Scheuner MT, Raffel LJ, Wang S-J, Rotter II. The family history: A comprehensive genetic risk assessment method for the chronic conditions of adulthood. Am J Med Genet 1997;71:315-324.

13. Ford D, Easton DF, Stratton M, Narod S, Goldgar D, Devilee P, Bishop DT, Weber B, Lenoir G, Chang-Claude J, Sobol H, Teare MD, Struewing J, Arason A, Scherneck S, Peto J, Rebeck TR, Tonin P, Neuhausen S, Barkardottir R, Eyfjord J, Lynch H, Ponder BAJ, Gayther SA, Birch JM, Lindblom A, Stoppa-Lyonnet D, Bignon X, Borg A, Hamann U, Haites N, Scott RJ, Maugard CM, Vasen H, Seitz S, Cannon-Albright LA, Schofield A, Zelada, Hedman M, and the Breast Cancer Linkage Consortium. Genetic heterogeneity and penetrance analysis of the BRCA1 and BRCA2 genes in breast cancer families. Am J Hum Genet 1998;62:676-689.

14. Foulkes WD, Brunet J-S, Warner E, Goodwin PJ, Meschino W, Narod SA, Goss PE, Glendon $G$. The importance of a family history of breast cancer in predicting the presence of a BRCA mutation. Am J Hum Genet 1999;65:1776-1779.

15. Greenberg JH. Special oversight groups to add protections for population-based repository samples. An J Hum Genet 2000;66:745-747. 